\title{
Spatial and temporal variation in DMSP content in the invasive seaweed Codium fragile ssp. fragile: effects of temperature, light and grazing
}

\author{
D. A. Lyons ${ }^{1,3, *}$, R. E. Scheibling ${ }^{1}$, K. L. Van Alstyne ${ }^{2}$ \\ ${ }^{1}$ Department of Biology, Dalhousie University, Halifax, Nova Scotia, B3H 4J1, Canada \\ ${ }^{2}$ Shannon Point Marine Center, Western Washington University, 1900 Shannon Point Road, Anacortes, Washington 98221, USA \\ ${ }^{3}$ Present address: Department of Biological Sciences, University of Alberta, Edmonton, Alberta, T6G 2E9, Canada
}

\begin{abstract}
The methionine-derived secondary metabolite dimethylsulfoniopropionate (DMSP) is believed to function in cryoprotection, defense against herbivory, and reduction of oxidative stress in some seaweeds. The ability to produce DMSP, and modify its concentration according to environmental conditions, may confer adaptive advantages to these algae. We studied the spatial and temporal distribution of DMSP content in Codium fragile off the Atlantic coast of Nova Scotia. Levels of DMSP in C. fragile were highest in boreal spring ( $2 \%$ of total dry wt) and lowest in fall $(\sim 1 \%)$, and negatively related to seawater temperature. DMSP content differed among sites and tended to decrease or remain constant with depth. In tide pools, partially bleached algae contained less DMSP than undamaged individuals, consistent with the putative function of DMSP in response to oxidative stress. Results of field- and laboratory-based experiments, designed to examine plasticity in DMSP production by $C$. fragile, indicate that it increases with light intensity, exposure to sea urchin grazing, and decreasing temperature.
\end{abstract}

KEY WORDS: Codium fragile $\cdot$ DMSP $\cdot$ Grazing $\cdot$ Invasive seaweed $\cdot$ Light intensity $\cdot$ Temperature

\section{INTRODUCTION}

Marine algae produce a diverse array of chemical compounds that, unlike primary metabolites such as proteins and nucleic acids, are not essential to their normal growth or reproduction. Many of these algal secondary metabolites serve important ecological functions, including protection against herbivores and other natural enemies (Yates \& Peckol 1993, de Nys et al. 1995), alleopathic interactions with other algae (Schmidt \& Hansen 2001), and acclimation to changing or stressful environmental conditions (Kirst 1996, Karsten et al. 1996, Sunda et al. 2002). Quantitative variation in the concentration of secondary metabolites is common, and occurs over a range of spatial and temporal scales (Van Alstyne et al. 2001a). This variation can be generated by heritable differences between individuals (Wright et al. 2004, Haavisto et al. 2010) or by environmental factors, such as nutrient concentrations, herbivory, light, and temperature (Karsten et al. 1992, Yates \& Peckol 1993).

Although secondary metabolites can reduce mortality, enhance performance and limit the competition an alga experiences, their production is also associated with a number of costs. Furanone production is negatively correlated with fecundity in the red alga Delisea pulchra, and phlorotannin production is negatively correlated with growth in the brown alga Fucus vesiculosus (Dworjanyn et al. 2006, Jormalainen \& Ramsay 2009). Such costs, coupled with the often concentration-dependant functioning of secondary metabolites, create a condition where an alga might be expected to control allocation of resources towards secondary metabolites in response to demands for their ecological function (Cronin 2001). Furthermore, secondary metabolite concentrations may fall as they 
are exhausted through use, or if their production is deprioritized when resources are limited.

The methionine-derived compound dimethylsulfoniopropionate (DMSP) has a number of putative ecological and physiological functions in marine algae. Physiological functions attributed to DMSP and its associated compounds include osmotic acclimation, cryoprotection, and an antioxidant response to stress (Kirst 1996, Karsten et al. 1996, Sunda et al. 2002). DMSP production, and its enzymatic cleavage into dimethylsulfide (DMS) and acrylic acid, may serve as an overflow mechanism for excess carbon and sulfur, particularly under nitrogen limiting conditions or during protein turnover (Stefels 2000). Also, both DMS and acrylic acid play a role in the anti-grazing defense of marine macroalgae by deterring some species of sea urchins and snails (Van Alstyne et al. 2001b, Van Alstyne \& Houser 2003, Lyons et al. 2007).

In the present study, we document quantitative variation in the concentrations of DMSP in the invasive green alga Codium fragile ssp. fragile (formerly ssp. tomentosoides, Provan et al. 2008; Codium fragile hereafter), and investigate the role of environmental factors that may contribute to this variation through their influence on resource availability and the alga's requirements for DMSP's putative functions. The success of $C$. fragile as an introduced and invasive species has often been attributed to traits that may be linked to its production of DMSP: it flourishes under a wide range of environmental conditions, is tolerant of physiological stresses, and is undesirable for many generalist herbivores (Trowbridge 1998, Schaffelke \& Deane 2005). Here, we examine patterns in DMSP content in C. fragile at different sites, and depths within sites, in the rocky subtidal zone (and intertidal zone at one site) on the Atlantic coast of Nova Scotia, between 2004 and 2009. We also examine simple or interactive effects of water temperature, light intensity and herbivory on DMSP content in C. fragile in field and laboratory experiments. We predict that DMSP content will increase at low temperature and with increasing light intensity, consistent with its putative roles as a cryoprotectant and sink for excess sulfur and carbon, respectively. Consequently, we predict that DMSP content will decrease with depth in the winter, when light decreases with depth but temperature does not. In the summer, however, we predict that a decrease in both light and temperature with depth will have opposing effects on DMSP production or utilization, limiting variation in DMSP content in $C$. fragile across a depth gradient. Finally, we expect that DMSP content might decrease, or increase, in algae exposed to grazing and physiological stress depending on whether they respond to these stressors by using the existing DMSP pool or up-regulating DMSP synthesis.

\section{MATERIALS AND METHODS}

Field sites and sampling procedures. Samples of Codium fragile used to examine spatial and temporal variation in DMSP content were collected haphazardly by SCUBA from the shallow subtidal zone $(3-10 \mathrm{~m}$ depth) from several sites along the Atlantic coast of Nova Scotia, Canada (Fig. 1, Table 1). For the samples collected in February 2006 and August 2007, algae were collected from known depths: 4, 6 and $8 \mathrm{~m}$ at each site, except $8 \mathrm{~m}$ at Paddy's Head in February and $8 \mathrm{~m}$ at both Paddy's Head and The Lodge in August. In these cases no specimens were found. Algae were returned to Dalhousie University and placed in a 1851 tank with flow-through seawater at ambient water temperature overnight, prior to processing and measurement of DMSP content (see below). Water temperature was measured at $6 \mathrm{~m}$ depth at Birchy Head between August 2004 and July 2005, and at $4 \mathrm{~m}$ depth at The Lodge between July 2005 and May 2009, using HOBO Data Loggers (Onset Computer Corporation).

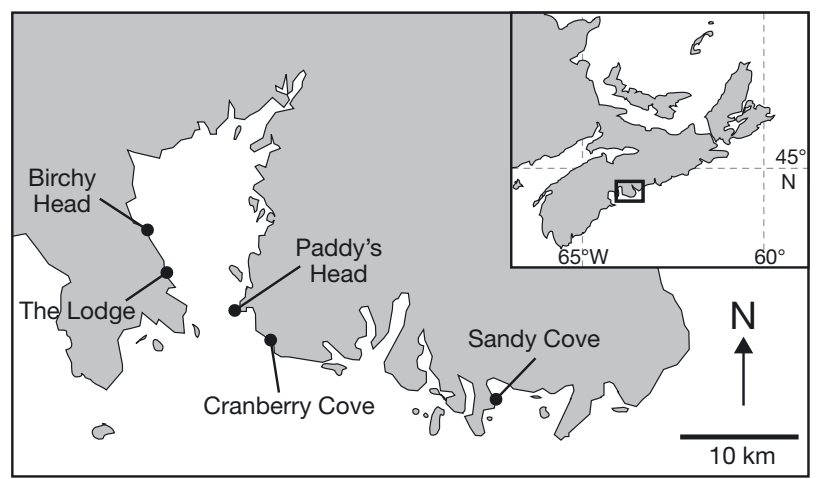

Fig. 1. Study sites along the Atlantic coast of Nova Scotia

Table 1. Codium fragile. Location and date of collection of subtidal specimens

\begin{tabular}{|c|c|c|}
\hline Site & Location & Date \\
\hline Birchy Head & $\begin{array}{l}44^{\circ} 35^{\prime} \mathrm{N} \\
64^{\circ} 03^{\prime} \mathrm{W}\end{array}$ & $\begin{array}{l}\text { September } 2004 \\
\text { March, May } 2005 \\
\text { February } 2006 \\
\text { August } 2007\end{array}$ \\
\hline Cranberry Cove & $\begin{array}{l}44^{\circ} 28^{\prime} \mathrm{N} \\
63^{\circ} 56^{\prime} \mathrm{W}\end{array}$ & $\begin{array}{l}\text { November } 2004 \\
\text { February } 2006 \\
\text { January, August } 2007 \\
\text { May } 2009\end{array}$ \\
\hline Sandy Cove & $\begin{array}{l}44^{\circ} 27^{\prime} \mathrm{N} \\
63^{\circ} 42^{\prime} \mathrm{W}\end{array}$ & July 2005 \\
\hline The Lodge & $\begin{array}{l}44^{\circ} 33^{\prime} \mathrm{N} \\
64^{\circ} 01^{\prime} \mathrm{W}\end{array}$ & $\begin{array}{l}\text { October } 2005 \\
\text { February } 2006 \\
\text { August } 2007\end{array}$ \\
\hline Paddy's Head & $\begin{array}{l}44^{\circ} 32^{\prime} \mathrm{N} \\
63^{\circ} 57^{\prime} \mathrm{W}\end{array}$ & $\begin{array}{l}\text { February } 2006 \\
\text { August } 2007\end{array}$ \\
\hline
\end{tabular}


To examine the effect of stress-induced bleaching on the DMSP content of intertidal Codium fragile we collected 20 individuals exhibiting signs of bleaching from a tide pool in the high intertidal zone near Cranberry Cove. Bleaching was evident as a whitish haze on the surface of the otherwise deep green algal thallus, typically on some of the distal ends (1 to $2 \mathrm{~cm}$ ) of branches. A few individuals also exhibited a small white patch (2 to $3 \mathrm{~mm}$ diameter) at the very tip of the affected branch. This is distinct from the discoloration described by other authors who noted that the alga 'bleaches' to a lighter shade of green in the summer and when grown under low nitrogen conditions (Head \& Carpenter 1975, Trowbridge 1998). We believe the bleaching we observed is caused by desiccation and/or light stress, as has been suggested for other algal species (Scrosati \& DeWreede 1998, Irving et al. 2004). We determined the DMSP content of 2 samples from each bleached thallus: 1 from a bleached portion of the thallus and 1 from a non-bleached portion. For comparison, we also collected 11 individuals from the same high tide pool that showed no signs of bleaching, and 9 individuals from a pool lower in the intertidal zone, where environmental conditions are likely to be less stressful.

Field transplantation experiment. We conducted a field transplantation experiment to investigate the potentially opposing effects of decreasing light (which may limit DMSP production in Codium fragile) and decreasing temperature (which may enhance production) with increasing depth. We predicted that, if temperature is the primary determinant of DMSP content in summer when the water column is stratified, thalli transplanted to a deeper depth should increase in DMSP content while those transplanted to a shallower depth should decrease. Alternatively, if light intensity is more important, the opposite should occur. On 2122 August 2007, experimental thalli were collected from 4 and $8 \mathrm{~m}$ depth at Cranberry Cove $(\mathrm{n}=72)$ and Birchy Head $(\mathrm{n}=64)$, and at $4 \mathrm{~m}$ (none occurred at $8 \mathrm{~m}$ ) at The Lodge $(n=30)$. Half of the thalli at each site were then transplanted back to their depth of origin, and half to the other depth. Transplanted thalli were attached at $50 \mathrm{~cm}$ intervals to a polypropylene rope, alternating thalli from each depth (except at The Lodge). The ropes were then anchored to a steel chain at each experimental depth at each site, allowing the transplants to assume a natural aspect and response to water motion. Transplanted thalli were collected for analysis on 10 September 2007. Water temperature at 4 and $8 \mathrm{~m}$ depth at each site was recorded using temperature loggers anchored to the bottom, as described in 'Field sites and sampling procedures'.

Effects of light, temperature, and grazing on DMSP content. We conducted 2 experiments to examine the effects of temperature or light on DMSP content in
Codium fragile under controlled conditions. Expt 1 examined the effect of temperature alone. A total of 66 individuals were collected from the shallow subtidal zone (3-8 m depth) at Cranberry Cove on 24 January 2007 and maintained in $185 \mathrm{l}$ tanks with flow-through seawater at ambient temperature prior to the experiment. On 21 February 2007, 11 thalli were randomly allocated to each of six 100-1 tanks. Two tanks were then randomly allocated to each of 3 water temperature treatments: ambient $\left(3^{\circ} \mathrm{C}\right)$, intermediate $\left(13^{\circ} \mathrm{C}\right)$ and high $\left(17^{\circ} \mathrm{C}\right)$. Over the next week, the temperatures in tanks assigned to the intermediate and high temperature treatments were gradually raised from ambient to the respective experimental temperatures. Thalli were kept in the tanks for another $8 \mathrm{~d}$ prior to sampling and analysis of DMSP concentrations.

Expt 2 examined the interactive effects of light intensity and temperature on DMSP content in Codium fragile. A total of 90 thalli were collected from the shallow subtidal zone (3 to $8 \mathrm{~m}$ depth) at Cranberry Cove on 14 May 2009, and maintained in flow-through tanks. After $1 \mathrm{~d}$, a distal section of a branch (10 to $15 \mathrm{~cm}$ long) was cut from each thallus and individually placed in a $500 \mathrm{ml}$ Ziploc ${ }^{\circledR}$ plastic jar. Each jar was perforated with twenty-two $1 \mathrm{~cm}$ diameter holes and weighted with a small amount of gravel. Ten jars with branches were placed in each of nine $47 \mathrm{l}$ aquaria with flow-through seawater. In each aquarium, 5 branches were randomly allocated to each of 2 light treatments: shaded and unshaded. Jars in the shaded treatment were painted black and covered with a double layer of $40 \%$ shade cloth. Unshaded jars were unpainted and uncovered except for 2 thin elastic bands stretched around the mouth, which retained buoyant algae. Three aquaria were randomly assigned to each of 3 water temperature treatments: ambient $\left(\sim 5^{\circ} \mathrm{C}\right)$, intermediate $\left(\sim 7^{\circ} \mathrm{C}\right)$, and high $\left(10^{\circ} \mathrm{C}\right)$. The initial position of each jar within an aquarium was randomly assigned and jars were rotated through the 10 positions, with each moving 1 position per day. A bank of lights containing four $1000 \mathrm{~W}$ phosphor-coated metal halide lamps and two $400 \mathrm{~W}$ mercury vapour lamps provided illumination on a $12 \mathrm{~h}$ light:12 h dark cycle. Light intensity ranged from 600 to $2100 \mathrm{~lx}$ among tanks for the shaded treatment, and from 3600 to $8000 \mathrm{~lx}$ for the unshaded treatment; shading consistently reduced light intensity by about 70 to $80 \%$ within tanks. After 15 d, samples were collected for measurement of DMSP content.

We also conducted 2 experiments to investigate the effects of sea urchin (Strongylocentrotus droebachiensis) grazing on DMSP content in Codium fragile and vice versa. For Expt 3, 24 thalli of $C$. fragile were collected at 3 to $8 \mathrm{~m}$ depth at Cranberry Cove, and 24 adult sea urchins (50 to $60 \mathrm{~mm}$ diameter) were collected at $8 \mathrm{~m}$ depth at Splitnose Point on 24 January 
2007, and maintained in separate flow-through tanks. On 1 February 2007, each thallus was divided at the basal bifurcation into 2 large fronds. One frond from each pair was placed in each half of twenty-four 471 aquaria, divided by plastic mesh ( $1 \mathrm{~cm}$ mesh size). One sea urchin was then randomly allocated to 1 of the 2 halves of each aquarium. This allowed the urchin to graze only on the frond in its half of the aquarium, while exposing the ungrazed frond to any chemical cues released from the urchin or the grazed frond. After $12 \mathrm{~d}$, the fronds were collected for measurement of DMSP content.

Expt 4 examined the effect of DMSP content in Codium fragile on the feeding rate of sea urchins. Twenty adult sea urchins (50 to $60 \mathrm{~mm}$ diameter) were collected at $6 \mathrm{~m}$ depth at Splitnose Point in May 2009 and maintained in flow-through tanks. After sampling for DMSP content (described below) at the end of Expt 2 , the unsampled portion of 15 branches of $C$. fragile were selected from the different treatment combinations to represent a range in DMSP content $(0.5$ to $2.6 \%$ dry wt). The branches were weighed and randomly assigned to each of twenty $946 \mathrm{ml}$ Ziploc ${ }^{\circledR}$ plastic containers containing 1 sea urchin, and perforated on all 4 sides with numerous $2 \mathrm{~mm}$ holes. Ten containers were randomly assigned to each of two $47 \mathrm{l}$ aquaria with flow-through seawater $\left(\sim 5^{\circ} \mathrm{C}\right)$. After $3 \mathrm{~d}$, the fronds were removed and reweighed to determine the amount consumed.

Measurement of DMSP content. Thalli or fronds of Codium fragile were blotted dry to remove excess water. A 3 to $4 \mathrm{~cm}$ long section of the distal end of a branch, typically weighing 0.8 to $1.5 \mathrm{~g}$, was dried to a constant weight at $60^{\circ} \mathrm{C}$ for $24 \mathrm{~h}$. Dried samples were shipped to Shannon Point Marine Center, Washington, USA for analysis. DMSP was measured as DMS, following alkaline cleavage in $4 \mathrm{~N} \mathrm{NaOH}$, by injecting $10 \mu \mathrm{l}$ headspace samples onto a Chromosil 330 column $\left(90^{\circ} \mathrm{C}\right.$ oven temperature) in an SRI gas chromatograph equipped with a flame photometric detector $\left(125^{\circ} \mathrm{C}\right.$ detector temperature). DMSP standard additions with commercially obtained DMSP (Center for Analysis, Spectroscopy and Synthesis, University of Groningen: purity $>98 \%$ ) added to equal volumes of $\mathrm{NaOH}$ were used to generate standard curves. The content of DMSP is expressed as percent dry wt (\% DW).

Statistical analysis. We examined temporal trends in the DMSP content of Codium fragile using periodic regression to determine seasonality. We fit 3 models by generalized least squares using the 'gnls' and 'gls' functions from the 'nmle' package (Pinheiro et al. 2009) in R version 2.10.1 (R Development Core Team 2009). Model 1 (the full model) was a periodic regression with a period of $1 \mathrm{yr}$, and included the site where the alga was collected as an additional factor:

$$
\mathrm{DMSP}_{i j}=b_{j}+A \cdot \sin \left[2 \pi\left(\mathrm{Time}_{i j}+\phi\right)\right]+\varepsilon_{i j}
$$

where DMSP $_{i j}$ is the DMSP content of individual $i$ at site $j, A$ is the population semi-amplitude of the cycle (from peak to mean), Time ${ }_{i j}$ is time (yr) since the initial sampling when individual $i$ was collected, $2 \pi$ gives the function a period of $1 \mathrm{yr}, \phi$ is a phase parameter that shifts the sine wave left or right, $b_{j}$ is the mean of the oscillation in DMSP content at site $j$, and $\varepsilon_{i j}$ is the residual error. We evaluated the importance of seasonality and site by comparing the full model to 2 reduced models using likelihood ratio tests. Reduced models included seasonality but not site (Model 2) or an effect of site but not time (Model 3). We did not have sufficient data to include a model that allowed the semiamplitude of the sine wave to differ between sites in our candidate set. To account for heterogeneous variance, we used the 'nlme' package's 'varIdent' variance function, which allows the variance to differ for each stratum (site by time combination in Model 1, time in Model 2, and site in Model 3). Samples from $\mathrm{n}=581$ individuals were used in these analyses.

Given the putative role of DMSP as a cryoprotectant, we hypothesized that one explanation for seasonal changes in DMSP concentrations was that Codium fragile alters its DMSP content in response to temperature. We used linear regression to examine the relationship between DMSP content and water temperature. We did not have temperature data for each site, so we used data from a single site that we believed to be representative of the conditions in our study area over the course of the study. As a result, we decided to run the analysis on the mean DMSP content from a given sampling period rather than run the analysis on the raw data, and have to choose between ignoring the influence of site or accidentally attributing variation due to temperature differences between sites during a sampling period to site effects. Changes in DMSP concentration are unlikely to occur instantaneously with changes in water temperature. Therefore, we initially fit a series of models using the average water temperature on the day that the algae were collected, as well as the temperature averaged for periods of time up to $24 \mathrm{~d}$ prior to collection, as explanatory variables. Temperature data were not available to construct thermal histories longer than $24 \mathrm{~d}$. This allowed us to determine the length of thermal history that gives the best prediction of DMSP content.

The additional information available for February 2006 and August 2007 samples allowed us to examine spatial variation in DMSP content more carefully and assess differences both between sites and over a depth gradient. We hypothesized that DMSP content would differ between sampling dates and sites. We also expected that the effect of depth would differ between 
winter and summer. We fit a linear model including site and month as categorical variables and depth as a continuous variable, as well as all possible interactions, by generalized least squares to evaluate this hypothesis. This is similar to an analysis of covariance model with 2 categorical variables, except that the variances need not be homogeneous. We compared the fit of this model to that of a nested model with no 3-way interaction using a likelihood ratio test to determine whether the 3-way interaction was important or if a simpler model could be used to explain variation in the data. Preliminary analyses suggested that variance increased with the mean, so we used the 'varPower' variance function in the 'nlme' package (Pinheiro et al. 2009) to allow the variance to increase as a function of the estimate raised to a power estimated from the data.

Data from the transplant experiment were analysed using linear models, fit by generalized least squares to deal with heterogeneous variances. Because of the lack of Codium fragile at $8 \mathrm{~m}$ at The Lodge, the design was unbalanced, so we elected to break down the analysis by the depth of origin of the alga. This allowed us to examine the influence of transplantation depth, site, and the potential interaction between these factors for algae originally collected from 4 or $8 \mathrm{~m}$. We used the 'varIdent' function to allow variances to differ among different treatment groups. The importance of terms in the full model was evaluated through comparisons with reduced models by likelihood ratio tests.

Analysis of variance (ANOVA) was used to compare samples of unbleached fronds across tide pools, followed by planned comparisons using a $t$-test with a Bonferroni adjustment $(\alpha=0.025)$. Bleached and unbleached samples from the same thalli were compared using a paired $t$-test. For laboratory Expts 1 and 2, examining effects of temperature and light intensity on DMSP content, mixed-model ANOVA with tank as a random factor nested within the temperature treatment was used to compare treatments. For Expt 3, examining the effect of grazing on DMSP content, paired samples were analyzed using a paired $t$-test. For Expt 4, linear regression was used to examine the relationship between consumption of Codium fragile by sea urchins and DMSP content.

\section{RESULTS}

\section{Temporal and spatial variation in dmsp content in subtidal populations}

Codium fragile exhibited marked seasonal variation in DMSP content, and mean DMSP content varied among sites, as indicated by the strong support for our full model compared to reduced models that did not include an effect of sampling site or a $1 \mathrm{yr}$ cycle in DMSP content (Model 1 vs. Model 2: likelihood ratio = 237.16, $\mathrm{p}<0.001$; Model 1 vs. Model 3: likelihood ratio $=917.14, \mathrm{p}<0.001$, Fig. $2 \mathrm{~A})$. The seasonal cycle had a semi-amplitude of $0.59 \%$ DMSP content, with the highest levels in late winter and early spring $(\sim 2 \%)$ and lowest levels in fall $(\sim 1 \%)$, over the $5 \mathrm{yr}$ study (Table 2, Fig. 2A). Differences among sites were smaller than seasonal changes. Estimates of mean DMSP content during the study ranged from $1.27 \%$ DW at Birchy Head to $1.69 \%$ DW at Paddy's Head
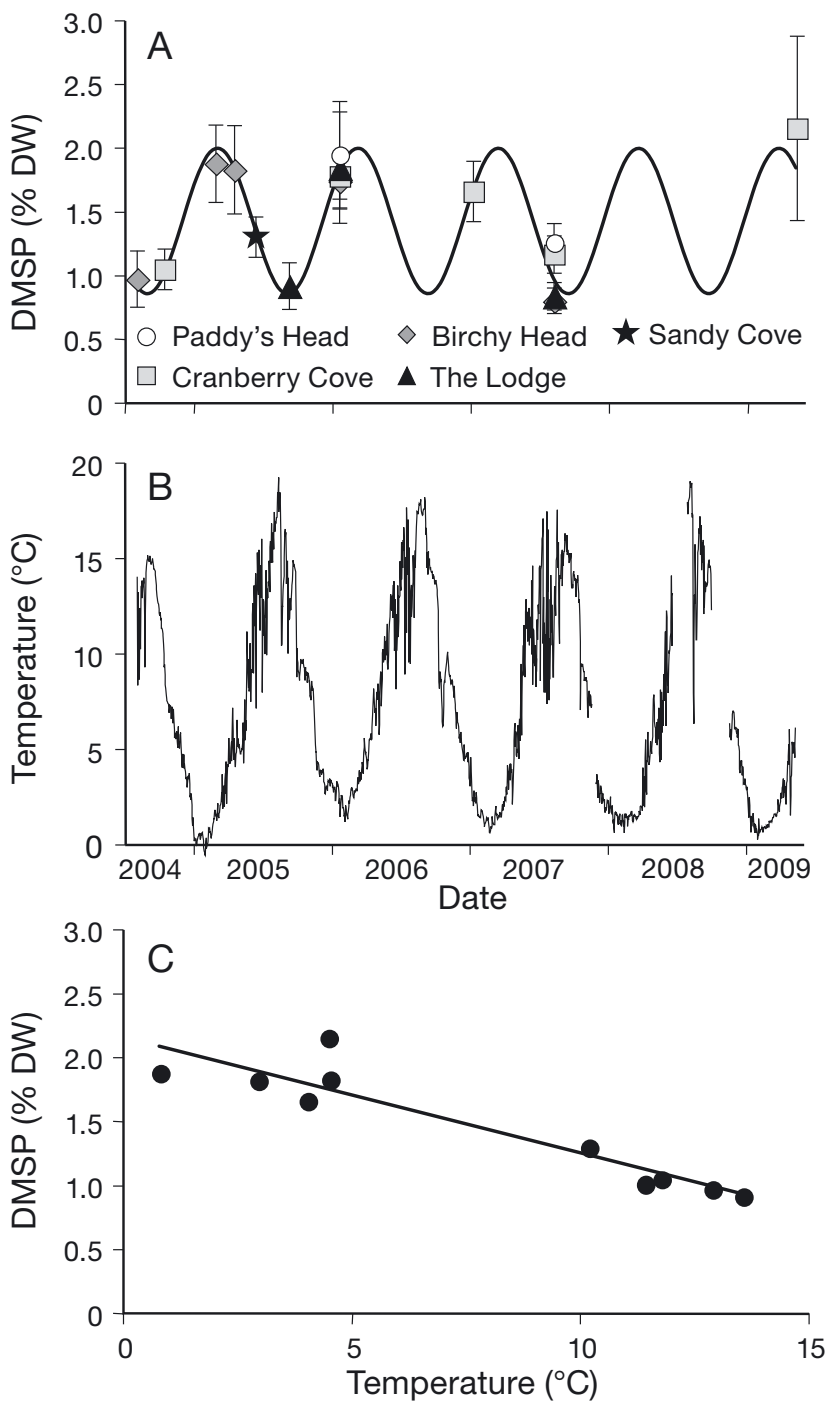

Fig. 2. Codium fragile. (A) DMSP content (mean \pm SD, \% dry wt) of subtidal algal populations between September 2004 and May $2009(\mathrm{n}=581)$. Line is the prediction of the periodic regression, averaged over the different sites for visual clarity. (B) Water temperature during the study. (C) Relationship between mean DMSP content in algal samples collected throughout the study and mean water temperature over $23 \mathrm{~d}$ prior to measurement of DMSP in each sample. Line is the prediction of the linear regression 
Table 2. Codium fragile. Estimates, SE, and $t$-values (all significant at $\mathrm{p}<0.001$ ) for parameters in the periodic regression model of DMSP content in response to site and time. $\mathrm{BH}=$ Birchy Head, $\mathrm{CC}=$ Cranberry Cove, $\mathrm{TL}=$ The Lodge, $\mathrm{PH}=$ Paddy's Head, and SC $=$ Sandy Cove.

\begin{tabular}{|lrrr|}
\hline Model parameter & Estimate & SE & $t$-value \\
\hline Semi-amplitude $(A)$ & -0.59 & 0.02 & 25.79 \\
Phase $(\phi)$ & 1.04 & 0.04 & 27.20 \\
BH mean $\left(b_{1}\right)$ & 1.27 & 0.01 & 93.52 \\
CC mean $\left(b_{2}\right)$ & 1.52 & 0.02 & 90.92 \\
TL mean $\left(b_{3}\right)$ & 1.31 & 0.02 & 69.55 \\
PH mean $\left(b_{4}\right)$ & 1.69 & 0.02 & 73.50 \\
SC mean $\left(b_{5}\right)$ & 1.32 & 0.04 & 2.57 \\
\hline
\end{tabular}

(Table 2). Regression analysis indicated that mean DMSP content at each sampling period was inversely related to average water temperature prior to collection. The model using a $23 \mathrm{~d}$ thermal history provided the best fit to the data according to the amount of variation explained and the corrected Akaike's information criterion values of the different models. This model indicated that DMSP content decreases by $0.09 \% \mathrm{DW}$ with an increase of $1{ }^{\circ} \mathrm{C}\left(\mathrm{r}^{2}=0.87, \mathrm{p}<0.001\right.$, $\mathrm{n}=10$, Fig. 2B). Models using different thermal history durations produced similar results $\left(\mathrm{r}^{2}=0.63\right.$ to $0.86, \mathrm{p}<$ 0.007, slope $=-0.8$ to -0.9 ) .

Additional evidence of spatial variation in DMSP content of Codium fragile was provided by our more detailed analysis for February 2006 and August 2007. The likelihood ratio comparing the full model to a reduced model indicated the importance of the 3-way interaction (likelihood ratio $=36.5, \mathrm{p}<0.0001$ ), i.e. differences in the effect of depth among sites in February 2006 differed from the pattern of differences in August 2007. DMSP content decreased sharply with depth at Paddy's Head $\left(0.22 \% \mathrm{DW} \mathrm{m}^{-1}\right)$ and The Lodge $(0.21 \%$ DW $\mathrm{m}^{-1}$ ) in February 2006, but decreased only slightly at Birchy Head $\left(0.04 \% \mathrm{DW} \mathrm{m}^{-1}\right)$ and was constant across depths at Cranberry Cove (Fig. 3). In August 2007, DMSP content decreased slightly with depth at The Lodge $\left(0.05 \% \mathrm{DW} \mathrm{m}^{-1}\right)$ and Birchy Head $(0.03 \%$ DW $\mathrm{m}^{-1}$ ), but was relatively constant across depths at Paddy's Head and Cranberry Cove (Fig. 3).

\section{Variation in DMSP content of bleached and undamaged thalli in intertidal populations}

DMSP content of Codium fragile collected from tide pools in April 2006 was markedly lower $(0.15$ to $0.30 \%$ DW, Fig. 4) than that measured in samples from subtidal populations ( 0.80 to $2.15 \%$ DW, Fig. 2). Samples of bleached fronds of $C$. fragile from a high intertidal pool

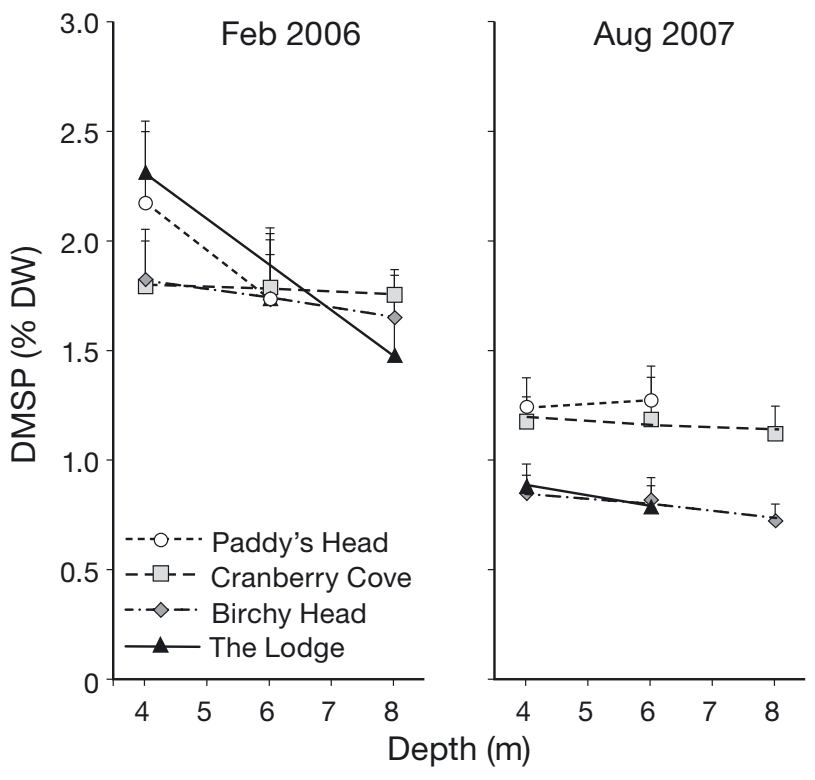

Fig. 3. Codium fragile. DMSP content (mean $+\mathrm{SD}, \%$ dry wt) of algae collected at 4,6 , and $8 \mathrm{~m}$ depth at 4 sites in February 2006 and August 2007 ( $n=20)$. Lines are linear trends in DMSP content with depth

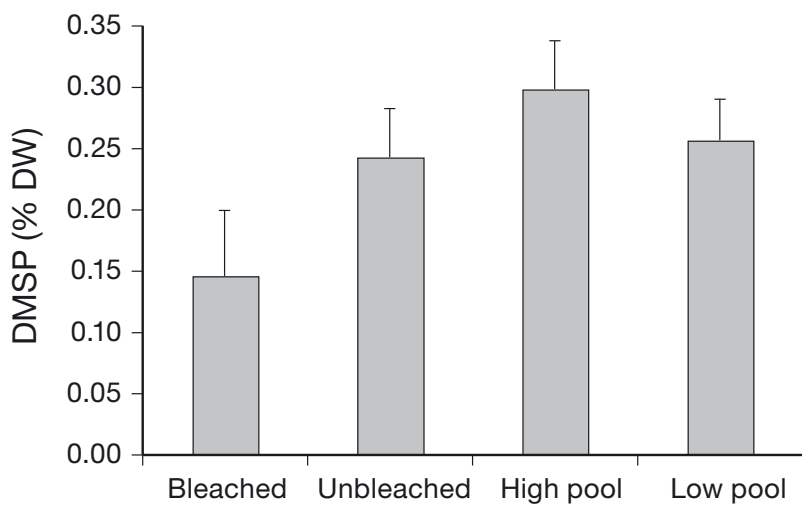

Fig. 4. Codium fragile. DMSP content (mean $+\mathrm{SD}$, \% dry wt) of paired branches from the same thallus that were bleached or undamaged $(\mathrm{n}=20)$, and of branches of undamaged thalli that were collected concurrently from the same high tide pool $(\mathrm{n}=11)$ or a low tide pool $(\mathrm{n}=9)$

contained significantly less DMSP than samples from apparently undamaged fronds on the same thallus (paired samples $t$-test, $t_{19}=8.4131, \mathrm{p}<0.001$ ). Samples from apparently undamaged parts of bleached thalli, undamaged thalli from the same high pool, and thalli from a low pool where there was no evidence of bleaching, differed in DMSP content $\left(F_{3,37}=7.38, \mathrm{p}=\right.$ 0.002). Thalli from the high tide pool with no bleaching damage had significantly higher levels of DMSP than undamaged fronds from bleached algae and algae from the low pool ( $t$-tests, $\alpha=0.025)$. 


\section{Field transplantation experiment: effect of depth on DMSP content}

Codium fragile originally collected from $4 \mathrm{~m}$ depth contained less DMSP when transplanted to $8 \mathrm{~m}$, than when transplanted back to $4 \mathrm{~m}$ (8 $\mathrm{m}$ depth effect estimated by model: $-0.10 \pm 0.03 \% \mathrm{DW}$, likelihood ratio $=$ 86.40, p $<0.001$, Fig. 5). The alga also differed in its DMSP content among sites (likelihood ratio $=45.28, \mathrm{p}$ $<0.001$ ), with estimated means ranging from $0.94 \%$ DW at Birchy Head to $1.17 \%$ DW at Cranberry Cove.

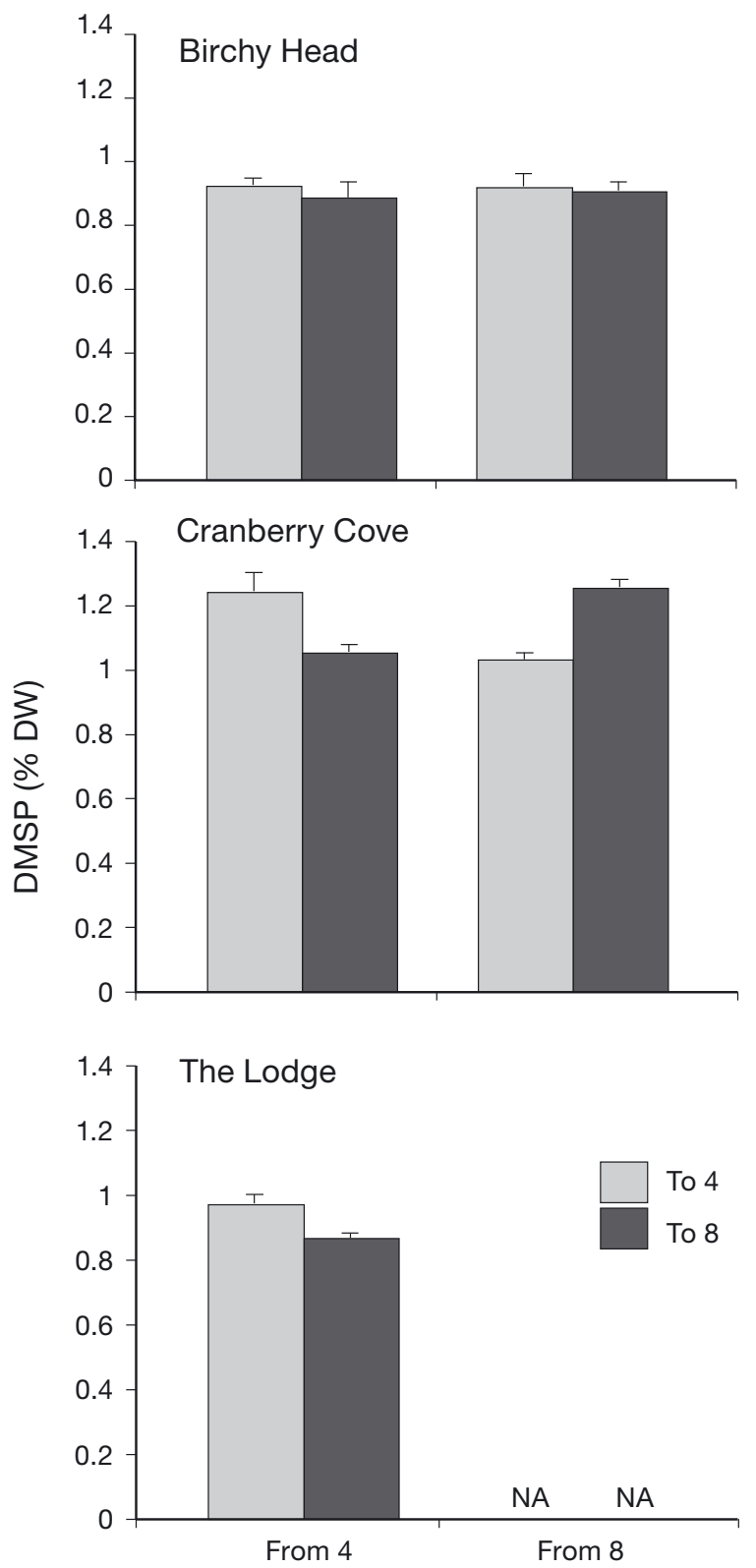

Fig. 5. Codium fragile. DMSP content (mean + SE, \% dry wt) of algae collected from, and transplanted to, 4 and $8 \mathrm{~m}$ depth at 3 sites ( $\mathrm{n}=15$ to 18 ). NA indicates that attached thalli were not found
There was little indication that the interaction between site and depth was important (likelihood ratio $=3.41$, $\mathrm{p}=0.182$ ). For algae originally collected from $8 \mathrm{~m}$, there was an important interaction between site and depth (likelihood ratio $=14.59, \mathrm{p}<0.001$ ), reflecting similar DMSP content in algae transplanted to both depths at Birchy Head (0.92 to $0.93 \%$ DW) and, in contrast to algae collected from $4 \mathrm{~m}$, higher DMSP content in algae transplanted to $8 \mathrm{~m}(1.27 \% \mathrm{DW})$ than those transplanted to $4 \mathrm{~m}(1.03 \% \mathrm{DW})$ at Cranberry Cove (Fig. 5).

\section{Effects of temperature, light intensity and grazing on DMSP content}

In Expt 1, thalli of Codium fragile maintained at ambient seawater temperature $\left(3^{\circ} \mathrm{C}\right)$ had significantly higher DMSP content than those warmed to 13 or $17^{\circ} \mathrm{C}$, which did not differ significantly (Tukey's test, $\alpha=0.05$ ) (Table 3, Fig. 6). In Expt 2, light intensity had

Table 3. Codium fragile. Results of mixed model ANOVA comparing the DMSP content in algae maintained at 3, 13 and $17^{\circ} \mathrm{C}$ (Expt 1), and shaded or unshaded algae maintained at 5, 7 and $10^{\circ} \mathrm{C}$ (Expt 2). P-values for significant factors are in bold

\begin{tabular}{|c|c|c|c|}
\hline Source $_{(\mathrm{df})}$ & Mean square & F-ratio & p-value \\
\hline \multicolumn{4}{|l|}{ Expt 1} \\
\hline Temperature $_{(2,3)}$ & 4.418 & 80.3 & 0.002 \\
\hline Tank (Temp) & 0.055 & 2.29 & 0.087 \\
\hline Error $_{(60)}$ & 0.024 & & \\
\hline \multicolumn{4}{|l|}{ Expt 2} \\
\hline Temperature $_{(2,6.14)}$ & 0.309 & 2.87 & 0.132 \\
\hline Tank (Temp) & 0.107 & 0.69 & 0.665 \\
\hline Light $(1,6.15)$ & 2.015 & 13.0 & 0.011 \\
\hline Temp $\times$ Light $_{(2,6.10)}$ & 0.189 & 1.22 & 0.359 \\
\hline Tank $\times$ Light $(6,69)$ & 0.154 & 0.54 & 0.776 \\
\hline Error $_{(69)}$ & 0.285 & 2.87 & \\
\hline
\end{tabular}

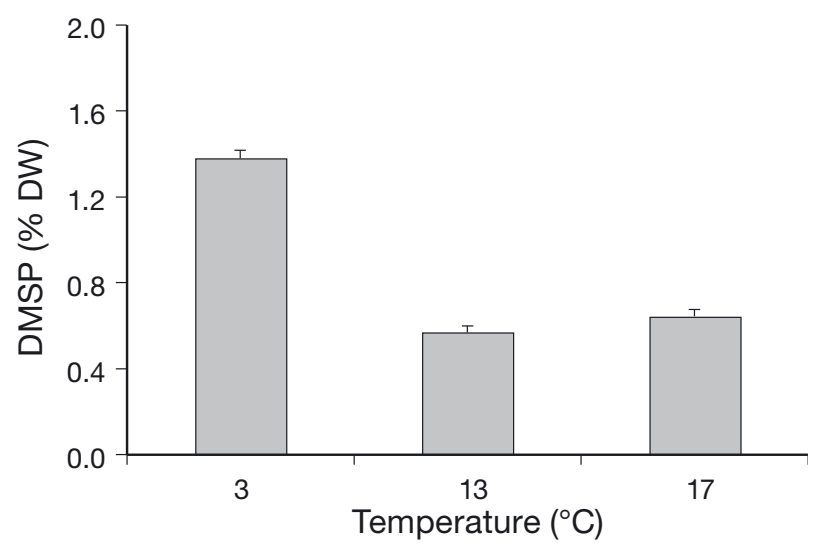

Fig. 6. Codium fragile. DMSP content (mean $+\mathrm{SE}$, \% dry wt) of algae at 3 temperatures in Expt 1 


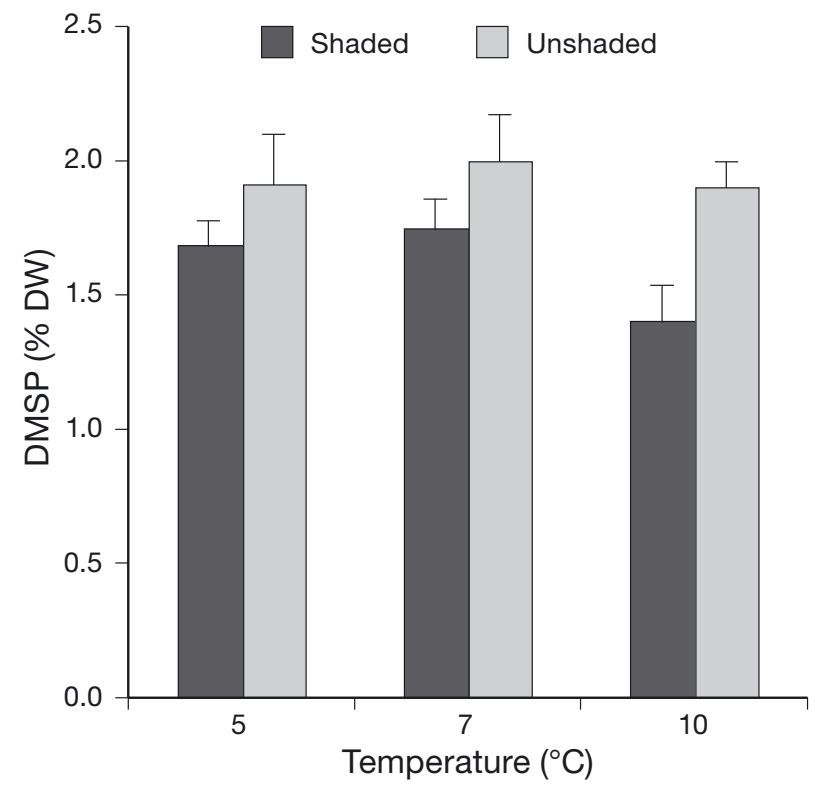

Fig. 7: Codium fragile. DMSP content (mean + SE, \% dry wt) of algae in factorial combinations of 2 levels of light intensity and 3 levels of temperature in Expt 2

a significant effect on DMSP content, with unshaded thalli containing more DMSP than shaded ones, but the effect of temperature was non-significant and there was no interaction between light intensity and temperature (Table 3, Fig. 7).

In Expt 3, DMSP content of fronds of Codium fragile directly exposed to sea urchin grazing for $14 \mathrm{~d}(1.60 \pm$ $0.05 \mathrm{SE}$ ) was significantly greater than that of fronds exposed only to waterborne cues from the grazers $(1.43 \pm 0.06 \mathrm{SE})$ (paired $t$-test, $\left.t_{23}=2.5671, \mathrm{p}<0.017\right)$. In Expt 4, there was no relationship between DMSP content of a thallus and the amount of algae consumed by urchins over $3 \mathrm{~d}\left(\mathrm{r}^{2}=0.15, \mathrm{p}=0.113\right)$.

\section{DISCUSSION}

\section{Effects of light and temperature on DMSP content of Codium fragile in subtidal habitats}

The DMSP content of Codium fragile undergoes a seasonal cycle, peaking in late winter or early spring when the alga contains roughly twice as much DMSP as it does in fall. Our results suggest that a response by the alga to changing water temperatures may largely account for this cycle. Mean water temperature explained $87 \%$ of the variation in the mean DMSP content of subtidal populations during our 5 yr study, with DMSP decreasing as temperature increased. A significant effect of temperature on DMSP content of the alga was detected in Expt 1 where experimental tempera- tures spanned $14^{\circ} \mathrm{C}$, though not in Expt 2 where temperatures spanned only $5^{\circ} \mathrm{C}$. Similarly, several species of Antarctic green algae (Ulotrix implexa, U. subflaccida, Enteromorpha bulbosa, and Acrosiphonia arcta) contain more DMSP when grown in the laboratory at $0^{\circ} \mathrm{C}$ than at $10^{\circ} \mathrm{C}$ (Karsten et al. 1992), and there is a trend of increasing DMSP content in algal species towards the poles (Van Alstyne \& Puglisi 2007). These patterns are consistent with a putative cryoprotective function of DMSP, which has been supported by experiments showing that DMSP enhances enzymatic activity at $-2^{\circ} \mathrm{C}$ or after a freeze-thaw cycle (Karsten et al. 1996). Water temperature occasionally drops slightly below $0^{\circ} \mathrm{C}$ off Nova Scotia (Fig. 2B), and intertidal algae are exposed to even colder temperatures, so it is possible that $C$. fragile attains cryoprotective benefits by increasing DMSP production through the winter. Alternatively, rates of DMSP synthesis may remain relatively stable and DMSP may accumulate at lower temperatures because of an inhibitory effect on DMSPlyase activity (Stefels \& Dijkhuizen 1996). The change in DMSP content in response to temperature change appears to occur over weeks, which is comparable to response times observed in other green algal species to changes in salinity (Van Alstyne et al. 2003) or light (Karsten et al. 1991).

Although the timing of temperature changes can vary somewhat among sites in our study area, temperature patterns are generally similar (Saunders \& Metaxas 2008) and thus unlikely to explain differences among sites in the DMSP content of Codium fragile. Water temperature has the potential to influence the DMSP content of $C$. fragile across a depth gradient in the summer, when the water column is stratified and temperature differences of several degrees can occur over depth scales of meters, and persist for weeks. However, the results of our laboratory experiments suggest that temperature differences $>5^{\circ} \mathrm{C}$ may be required. During summer, the effect of decreasing temperature with depth on DMSP content may be counteracted by concomitant decreases in light intensity and changes in spectral quality. Our finding that DMSP content in August 2007 decreased slightly with depth at 2 sites - was similar across depths at 2 others, and was higher at $4 \mathrm{~m}$ than at $8 \mathrm{~m}$ in 4 of the 5 sets of transplants - suggests that the negative effect of light attenuation with depth is generally equal to, or stronger than, any positive effect of decreasing temperature with depth. The pattern of decreasing DMSP in C. fragile with depth at The Lodge, Birchy Head, and Paddy's Head in February 2006 is also consistent with a positive correlation between light intensity and DMSP accumulation.

DMSP content in algae is known to increase with light intensity when light levels are below saturation 
for photosynthesis. Photosynthesis is required for production of methionine, the precursor to DMSP (Stefels 2000, Van Alstyne 2008), which may in turn regulate DMSP production. The positive effect of light on DMSP content that we observed is also consistent with the hypothesis that DMSP serves as an overflow mechanism for excess carbon and reduced sulfur when the rate of carbon assimilation exceeds that of protein synthesis (Stefels 2000). The regulatory effect of light intensity on DMSP production can be complex. For example, DMSP content of Urospora penicilliformis increases with light intensity when grown under a 16:8 h, but not a 8:16 h, light:dark cycle (Karsten et al. 1990).

The similarity in DMSP content of Codium fragile across depths at Cranberry Cove in February 2006 cannot be explained by opposing influences of temperature and light because the water column was well mixed. Other environmental variables that affect DMSP production in algae, including salinity (Karsten et al. 1992) and nitrogen concentration (Gröne \& Kirst 1992), are also unlikely to have varied with sampling depth at this time. In our reciprocal transplant experiment at Cranberry Cove, $C$. fragile originating from $4 \mathrm{~m}$ depth had a greater DMSP content in the $4 \mathrm{~m}$ transplants; however, thalli from $8 \mathrm{~m}$ that were transplanted to $4 \mathrm{~m}$ contained less DMSP than those back transplanted at $8 \mathrm{~m}$. If a change in DMSP content is environmentally induced, this would require algae originating from each depth to respond differently to changes in environmental variables at the transplanted depth. Alternatively, thalli transplanted to a different environment may release DMSP in response to physiological stress (Sunda et al. 2002). This could account for the decrease in DMSP content of thalli transplanted to a different depth, regardless of their original depth.

\section{Bleaching and DMSP content of Codium fragile in tide pools}

Bleaching has been previously recorded in Codium fragile (Schmidt \& Scheibling 2005) and other intertidal algae (e.g. Chondrus crispus, Mazzaella cornucopiae, and Lithophyllum sp.) in association with physiological stressors, such as extreme temperatures, desiccation, or unusually high light levels (Dudgeon et al. 1990, Scrosati \& DeWreede 1998, Irving et al. 2004). We observed bleaching of $C$. fragile in a high intertidal pool, where such stresses are likely to be more intense than in pools lower on the shore or in the subtidal zone. These extreme conditions can also cause oxidative stress in algae, characterized by the production and accumulation of reactive oxygen species that can damage lipids, proteins, and nucleic acids (Lesser 2006).
DMSP production and lysis may function in the physiological response of algae to oxidative stress (Sunda et al. 2002). Ross \& Van Alstyne (2007) found that the tissue concentrations of DMSP in Ulva lactuca decreased with exposure to increasing concentrations of hydrogen peroxide, as DMS and acrylic acid, both antioxidants, were released. Our finding that bleached fronds contained less DMSP than unbleached fronds from the same thallus, and that those non-bleached fronds contained less DMSP than algae from the same tide pool with no obvious signs of stress, is consistent with the conversion of DMSP to DMS and acrylic acid in response to stress.

Although oxidative stress may result in a reduction of DMSP content, it could also cause algae to up-regulate DMSP production (Sunda et al. 2002). It is not clear if this occurs in Codium fragile, but our finding that algae from the high pool displayed higher DMSP content than those from the low pool is consistent with increased synthesis in a more stressful environment, although the low levels of DMSP in intertidal algae compared to subtidal algae is not. Ulva lactuca in intertidal habitats also contain less DMSP than their subtidal counterparts. However, intertidal U. lactuca also produce less hydrogen peroxide when subjected to osmotic or desiccation stress, lose less DMSP when stressed, and exhibit greater antioxidant activity, suggesting they are better acclimated to stressful environments despite their lower DMSP content (Ross \& Van Alstyne 2007). Clearly, algae can use mechanisms other than DMSP accumulation to deal with stressful environments, and the elevated DMSP content of algae in the high pool could have been caused by some other factor, such as increased light intensity.

\section{Grazing and DMSP content of Codium fragile}

Herbivory is believed to have contributed to the evolution of novel chemical defenses or enhancement of existing defenses in a wide range of organisms (Ehrlich \& Raven 1964, Rausher 2001). However, some macroalgae respond to herbivory over shorter time scales by mobilizing 'inducible defenses', produced at higher levels once an alga is damaged by herbivores (Van Alstyne 1988, Yates \& Peckol 1993, Cronin \& Hay 1996). Others produce 'activated defenses' that are stored within the alga in an inactive or less active form, and converted into the defensive form upon grazing damage (Paul \& Van Alstyne 1992, Cetrulo \& Hay 2000).

The production of DMSP, and its lysis to DMS and acrylic acid, is considered an activated defense (Van Alstyne et al. 2001b, Van Alstyne \& Houser 2003). We found that fronds of Codium fragile directly exposed to 
urchin grazing had $11 \%$ higher DMSP content than those maintained in the same aquarium without direct contact with the urchins (Expt 3), suggesting it may also be an inducible defense. However, this increase is relatively small, compared to temporal changes and individual variation that we observed during our study, and such differences do not appear to affect the feeding rate of urchins on fronds of $C$. fragile (Expt 4). This finding is consistent with our previous experiments with agar-based foods, which showed that the feeding rate of Strongylocentrotus droebachiensis was unaffected by the concentration of DMS and acrylic acid (Lyons et al. 2007). Nevertheless, induction of DMSP by grazing damage might be sufficient to limit consumption rates of $C$. fragile in a natural setting where there are alternative algal foods, as both DMS and acrylic acid can influence food choice (Lyons et al. 2007). Furthermore, this induction could potentially affect the grazing of other herbivores. Defenses induced by one herbivore can reduce the feeding of competing herbivore species, in some cases to a greater degree than the species that caused the induction initially (Long et al. 2007). Investigating these possibilities with $C$. fragile could be an interesting avenue for future research.

\section{CONCLUSIONS}

In this study, we documented significant temporal and spatial variation in the DMSP content of Codium fragile and identified water temperature, light intensity, herbivory, and physiological stress as factors that contribute to variation in the DMSP content of this species. Consistent with our predictions, DMSP content increased with light intensity and decreased with temperature. Our prediction that DMSP content would vary more with depth in the winter than in the summer received partial support, as the greatest difference we observed between depths occurred in the winter. However, DMSP content changed with depth at some sites, but not others, in both seasons, suggesting that some variable(s) we did not consider may also affect DMSP accumulation by $C$. fragile. The alga increases its DMSP content in response to grazing damage, suggesting an inducible defense. Thalli exhibiting signs of physiological stress have lower levels of DMSP, consistent with its use as an antioxidant, and apparently healthy individuals living in the high intertidal zone (where stress is greater) contain more DMSP than those lower on the shore. These findings suggest that $C$. fragile utilizes DMSP in various ways that contribute to the alga's eurytropicity, low herbivore preference, and potentially its success as an invasive species.
Acknowledgements. The authors thank J. Lindley, A. Schmidt, O. D'Amours, P. Gagnon, K. Krumhansl, J. S. Lauzon-Guay, L. Sauchyn, and S. Clemente for help with fieldwork, M. Saunders and A. Yorke for providing the water temperature data, M. Auger-Méthé for statistical advice, and S. A. Gifford for help with laboratory analyses. This research was supported by an NSERC Discovery grant to R.E.S., National Science Foundation grants (OCE-0526644 and IOS 0717631) to K.L.V., and scholarships from NSERC and the Killam Trust to D.A.L.

\section{LITERATURE CITED}

Cetrulo GL, Hay ME (2000) Activated chemical defenses in tropical versus temperate seaweeds. Mar Ecol Prog Ser 207:243-253

Cronin G (2001) Resource allocation in seaweeds and marine invertebrates: chemical defense patterns in relation to defense theories. In: McClintock JB, Baker BJ (eds) Marine chemical ecology. CRC Press, Boca Raton, FL, p 325-353

- Cronin G, Hay ME (1996) Induction of seaweed chemical defenses by amphipod grazing. Ecology 77:2287-2301

> de Nys R, Steinberg PD, Willemsen P, Dworjanyn SA, Gabelish CL, King RJ (1995) Broad spectrum effects of secondary metabolites from the red alga Delisea pulchra in antifouling assays. Biofouling 8:259-271

> Dudgeon SR, Davison IR, Vadas RL (1990) Freezing tolerance in the intertidal red algae Chondrus crispus and Mastocarpus stellatus: relative importance of acclimation and adaptation. Mar Biol 106:427-436

> Dworjanyn SA, Wright JT, Paul NA, de Nys R, Steinberg PD (2006) Cost of chemical defence in the red alga Delisea pulchra. Oikos 113:13-22

> Ehrlich PR, Raven PH (1964) Butterflies and plants: a study in coevolution. Evolution 18:586-608

> Gröne T, Kirst GO (1992) The effect of nitrogen deficiency, methionine and inhibitors of methionine metabolism on the DMSP contents of Tetraselmis subcordiformis (Stein). Mar Biol Lett 112:497-503

Haavisto F, Välikangas T, Jormalainen V (2010) Induced resistance in a brown alga: phlorotannins, genotypic variation and fitness costs for the crustacean herbivore. Oecologia 162:685-695

Head WD, Carpenter EJ (1975) Nitrogen fixation associated with the marine macroalga Codium fragile. Limnol Oceanogr 20:815-823

Irving AD, Connell SD, Elsdon TS (2004) Effects of kelp canopies on bleaching and photosynthetic activity of encrusting coralline algae. J Exp Mar Biol Ecol 310:1-12

Jormalainen V, Ramsay T (2009) Resistance of the brown alga Fucus vesiculosus to herbivory. Oikos 118:713-722

> Karsten U, Wiencke C, Kirst GO (1990) The effect of light intensity and daylength on the $\beta$-dimethylsulphoniopropionate (DMSP) content of marine green macroalgae from Antarctica. Plant Cell Environ 13:989-993

Karsten U, Wiencke C, Kirst GO (1991) Growth pattern and $\beta$-dimethylsulphoniopropionate (DMSP) content of green macroalgae at different irradiances. Mar Biol 108:151-155

Karsten U, Wiencke C, Kirst GO (1992) Dimethylsulphoniopropionate (DMSP) accumulation in green macroalgae from polar to temperate regions: interactive effects of light versus salinity and light versus temperature. Polar Biol 12: 603-607

Karsten U, Kück K, Vogt C, Kirst GO (1996) Dimethylsulfoniopropionate production in phototrophic organisms and its physiological function as a cryoprotectant. In: Kiene RP, Visscher RP, Keller MD, Kirst GO (eds) Biological and 
environmental chemistry of DMSP and related sulfonium compounds. Plenum Press, New York, NY, p 143-153

Kirst GO (1996) Osmotic adjustment in phytoplankton and macroalgae: The use of dimethylsulfoniopropionate (DMSP). In: Kiene RP, Visscher PT, Keller MD, Kirst GO (eds) Biological and environmental chemistry of DMSP and related sulfonium compounds. Plenum Press, New York, NY, p 121-129

Lesser MP (2006) Oxidative stress in marine environments: biochemistry and physiological ecology. Annu Rev Physiol 68:253-278

Long JD, Hamilton RS, Mitchell JL (2007) Asymmetric competition via induced resistance: specialist herbivores indirectly suppress generalist preference and populations. Ecology 88:1232-1240

Lyons DA, Van Alstyne KL, Scheibling RE (2007) Anti-grazing activity and seasonal variation of dimethylsulfoniopropionate-associated compounds in the invasive alga Codium fragile ssp. tomentosoides. Mar Biol 153:179-188

Paul VJ, Van Alstyne KL (1992) Activation of chemical defenses in the tropical green algae Halimeda spp. J Exp Mar Biol Ecol 160:191-203

Pinheiro J, Bates D, DebRoy S, Sarkar D, R Development Core team (2009) nlme: linear and nonlinear mixed effects models. $\mathrm{R}$ package version 3.1-93

Provan J, Booth D, Todd NP, Beatty GE, Maggs CA (2008) Tracking biological invasions in space and time: elucidating the invasive history of the green alga Codium fragile using old DNA. Divers Distrib 14:343-354

R Development Core Team (2009) R: A language and environment for statistical computing. Version 2.10.1. R Foundation for Statistical Computing, Vienna. www.R-project.org

Rausher MD (2001) Co-evolution and plant resistance to natural enemies. Nature 411:857-864

Ross C, Van Alstyne KL (2007) Intraspecific variation in stress-induced hydrogen peroxide scavenging by the ulvoid macroalga Ulva lactuca. J Phycol 43:466-474

Saunders M, Metaxas A (2008) High recruitment of the introduced bryozoan Membranipora membranacea is associated with kelp bed defoliation in Nova Scotia, Canada. Mar Ecol Prog Ser 369:139-151

Schaffelke B, Deane D (2005) Desiccation tolerance of the introduced marine green alga Codium fragile ssp tomentosoides - clues for likely transport vectors? Biol Invasions $7: 577-587$

Schmidt LE, Hansen PJ (2001) Allelopathy in the prymnesiophyte Chrysochromulina polylepis: effect of cell concentration, growth phase and $\mathrm{pH}$. Mar Ecol Prog Ser 216: 67-81

Schmidt AL, Scheibling RE (2005) Population dynamics of an

Editorial responsibility: Laura Airoldi,

Ravenna, Italy invasive green alga, Codium fragile subsp. tomentosoides, in tidepools on a rocky shore in Nova Scotia, Canada. Ecoscience 12:403-411

Scrosati R, DeWreede RE (1998) The impact of frond crowding on frond bleaching in the clonal intertidal alga Mazzaella cornucopiae (Rhodophyta, Gigartinaceae) from British Columbia, Canada. J Phycol 34:228-232

Stefels J (2000) Physiological aspects of the production and conversion of DMSP in marine algae and higher plants. J Sea Res 43:183-197

> Stefels J, Dijkhuizen L (1996) Characteristics of DMSP-lyase in Phaeocystis sp. (Prymnesiophyceae). Mar Ecol Prog Ser 131:307-313

> Sunda W, Kieber D, Kiene R, Huntsman S (2002) An antioxidant function for DMSP and DMS in marine algae. Nature 418:317-320

Trowbridge CD (1998) Ecology of the green macroalga Codium fragile (Suringar) Hariot 1889: invasive and noninvasive subspecies. Oceanogr Mar Biol Annu Rev 36:1-64

> Van Alstyne KL (1988) Herbivore grazing increases polyphenolic defenses in the intertidal brown alga Fucus distichus. Ecology 69:655-663

Van Alstyne KL (2008) Ecological and physiological roles of dimethylsulfoniopropionate and its products in marine macroalgae. In: Amsler CD (ed) Algal chemical ecology. Springer, Berlin, p 173-194

> Van Alstyne KL, Houser LT (2003) Dimethylsulfide release during macroinvertebrate grazing and its role as an activated chemical defense. Mar Ecol Prog Ser 250:175-181

- Van Alstyne KL, Puglisi MP (2007) DMSP in marine macroalgae and macroinvertebrates: distribution, function, and ecological impacts. Aquat Sci 69:394-402

Van Alstyne KL, Dethier MN, Duggins DO (2001a) Spatial patterns in macroalgal chemical defenses. In: McClintock JB, Baker BJ (eds) Marine chemical ecology. CRC Press, Boca Raton, FL, p 301-324

> Van Alstyne KL, Wolfe GV, Freidenburg TL, Neill A, Hicken C (2001b) Activated defense systems in marine macroalgae: evidence for an ecological role for DMSP cleavage. Mar Ecol Prog Ser 213:53-65

> Van Alstyne KL, Pelletreau KN, Rosario K (2003) in the effects of salinity on dimethylsulfoniopropionate production in the green alga Ulva fenestrata Postels et Ruprecht (Chlorophyta). Bot Mar 46:350-356

- Wright J, De Nys R, Poore AGB, Steinberg PD (2004) Chemical defense in a marine alga: heritability and the potential for selection by herbivores. Ecology 85:2946-2959

> Yates JL, Peckol P (1993) Effects of nutrient availability and herbivory on polyphenolics in the seaweed Fucus vesiculosus. Ecology 74:1757-1766

Submitted: February 2, 2010; Accepted: September 8, 2010 Proofs received from author(s): October 27, 2010 